\title{
Policy Recommendations
}

\author{
Aiming for Effective Knowledge Transfer Policies \\ in High- and Middle-Income Countries
}

SUMA ATHREYE AND FEDERICA ROSSI

\subsection{Introduction}

Policy interventions supporting the transfer of knowledge from public research organizations, including universities and public research institutes, to industry, have been adopted in many countries around the world since the 1980s. This has led to a marked convergence in policies supporting knowledge transfer from the public science base in different countries. However, implementing similar policies in different innovation systems is full of pitfalls. Drawing on the six case studies in this book, which range from high- (United Kingdom, Germany, Republic of Korea) to middle-income countries (China, Brazil, South Africa), we show that, because the innovation systems in these countries were different, the implementation of similar knowledge transfer policies was supported by different sets of complementary polices. In fact, many middleincome countries were forced to compensate for institutional deficiencies with supporting policies that differed from those adopted by highincome countries.

In this chapter, we identify the different sets of complementary knowledge transfer policies implemented in high- and middle-income countries, evaluate their implications for the success of knowledge transfer processes, and develop policy recommendations. Briefly, we show that in high-income countries with mature national innovation systems, patterns of interaction between university and industry already existed, and the policy convergence merely incentivized the rearrangement of outcomes in the vector of possible outcomes that was outlined in Chapter 2. Thus, commercialization through patent licensing in Germany and the 
United Kingdom often replaced other established knowledge transfer channels. The policy challenge in these economies is to ensure all channels of knowledge transfer are appropriately nurtured. In middle-income economies, where patterns of interaction with industry are still developing, policy convergence needs a different set of complementary measures to succeed, which include incentives to researchers, changing the legal structure of university incomes to allow academics to earn income from consultancy and the use of public research institutes. These measures compensate for structural differences/deficiencies in national innovation systems. Identifying the appropriate complementary measures is therefore crucial for the success of knowledge transfer policy in both high- and middle-income economies.

As the international convergence of policies in support of university patenting and licensing through the allocation of intellectual property (IP) rights to universities was strongly inspired by US policy, we first revisit the case of the United States of America (U.S.) We then use the six case studies in this book to describe the process of convergence of knowledge transfer policies and the reasons for the substantial differences between the paths followed by the high- and middle-income countries. We highlight the different innovation systems in which these interventions were implemented, the different shapes that these interventions took, and why convergence in policy outcomes and in the overall knowledge transfer systems of these countries has not yet been reached. Finally, we conclude with implications for policy and further research.

\subsection{New Policies in Support of Knowledge Transfer from Public Science}

\subsubsection{The U.S. as a Model for Policy}

One of the most visible policy interventions in support of knowledge transfer to industry was the US Federal Government's implementation of the Bayh-Dole Act in 1980 (Mowery and Sampat 2005). As noted in Chapter 1, although this piece of legislation was not the first attempt by governments to regulate university IP - Israel had introduced university IP policies in the 1960s and the US government had already experimented with giving seventy universities the right to patent federal government-funded inventions since 1968 - the Bayh-Dole Act of 1980 was the most influential. The Act granted universities ownership of the IP emerging from their staff s federally funded research, which previously 
used to lie with the US Federal Government. The rationale for this move was to improve the commercialization of research findings by moving the ownership of the IP closer to the researchers and institutions involved and away from distant government offices. Sampat (2009) notes that the most commonly cited justification by proponents of Bayh-Dole-type legislation worldwide is that very few government-owned inventions were commercialized in the U.S. before 1981. For example, in a letter to the prime minister, arguing for an Indian Bayh-Dole act, the National Knowledge Commission noted:

In the United States, before the Bayh-Dole Act was enacted, the country's federal agencies owned about 28,000 patents, out of which only $5 \%$ were licensed to industry to develop commercial products (Pitroda 2007, as cited in Sampat 2009)

Policymakers were also concerned that unpatented university discoveries at an early stage of development would not be taken up by industry unless a patent provided firms with an incentive to invest in additional research for their commercialization (Berman 2008; Kenney and Patton 2009). Hence, Bayh-Dole was designed to encourage commercialization, particularly through permitting exclusive licensing and preferential access to public science for SMEs (Schacht 2005). However, the requirement to give preference to small businesses does not seem to have had much of an effect and may have been revised at a later date.

The years following the implementation of the Bayh-Dole Act saw the emergence of several blockbuster patents bringing very high economic returns to the institutions that owned them. One of these was the CohenBoyer patent (1980-97) for recombinant DNA, which during its seventeen-year term earned Stanford University USD 254 million (90 percent of which came from royalties on product sales), was licensed to 468 companies and used in 2,400 products (Feldman et al. 2005). Another example was the Axel patent for rDNA in mammalian cells, which earned Columbia University and its inventors USD 790 million (Colaianni and Cook Degan 2009). Yet another was the exclusive license for the drug Taxol given by the National Institutes of Health (NIH) and Florida State University to Bristol-Myers-Squibb (BMS). Florida State University earned more than USD 200 million in royalties from BMS (Powers 2006).

It is very likely that these very high-profile examples, combined with the general perception of the US national innovation system as being particularly successful in the development of advanced technology, inspired policymakers in other countries to implement similar policies. 
Graff (2007) notes that several countries, including India, Brazil, South Africa, Malaysia, and Jordan, debated or passed legislation modeled on the US Bayh-Dole Act.

The success of the Bayh-Dole legislation in the U.S. masks the fact that Bayh-Dole did not happen in isolation but was nested in a broader policy mix that aimed to transfer knowledge from the science base to industry. Block (2008) argues that the U.S. has been engaged since the 1970s in the creation of a "developmental network state" whose aim is to facilitate the translation of fundamental research into cutting-edge technologies. It has done so through the deployment of a broad range of interventions supporting the transfer of knowledge between university and industry, both on the "supply side" and also, very importantly, on the "demand side" (see also Bozeman 1994). Supply-side policies encouraged federal laboratories to engage with state and local government, universities, and private industry (Stevenson-Wydler Technology Innovation Act, 1980; Federal Technology Transfer Act, 1988). These policies also supported the formation of university research centers focused on translational research (Engineering Research Centers, 1985) as well as centers diffusing technologies developed by the Department of Defense to small firms (Defense Industrial and Technology Base Initiative, 1991). Complementary demand-side policies, by contrast, provided matching grants to firms investing in the commercialization of new technologies (Advanced Technology Program, 1988), earmarked a share of the budget of federal laboratories to support the research efforts of small firms (Small Business Innovation Development Act, 1982), encouraged collaborations between small firms and universities (Small Business Research and Development Enhancement Act, 1982), and incentivized firms' adoption of advanced technologies (Manufacturing Extension Program, 1988). Nevertheless, these additional interventions have not figured prominently in the mainstream policy discourse (Block 2008).

Equally important to note is the lack of any consensus on what created successful knowledge transfer in areas such as Silicon Valley. Along with the importance of particular universities, attention has also focused on other aspects of the innovation system, namely, the presence of superstar scientists who drew firms into their regions (Zucker et al. 1998), the presence of knowledge networks and conducive regional systems of innovation (Storper and Walker 1983; Saxenian 1994), and the role of diasporic labor and their transnational links (Saxenian 2007) that allowed nascent small-scale technological experiments in multiple locations and 
the smooth scale-up of successful innovations without running into labor and material shortages. These factors lurk in the background of the explanations of US Bayh-Dole successes, but are notable by their absence in other parts of the world.

\subsubsection{Convergence of Knowledge Transfer Policies}

Bayh-Dole-inspired legislation has been progressively implemented around the world since the early 1990s and particularly during the 2000s. In continental Europe - where there was a diversity of ownership arrangements for public sector science - most countries switched to university ownership between the mid-1990s and 2010 (Geuna and Rossi 2011). Early adopters of the university ownership system, such as Switzerland, the United Kingdom, France, and Spain, began to enforce it stringently from the 1990s. In other countries - Germany, Austria, and most of Scandinavia - the switch in university ownership was from a previous system of "professor's privilege," where academics owned the IP rights to their inventions and were able to dispose of them freely. Cambridge University, which had maintained a professor's privilege system, finally switched to university ownership in 2005. Currently, in Europe, only a few cases of inventor ownership systems remain - Sweden being the clearest example. Italy has a system combining aspects of both. Countries in the former Eastern bloc - Hungary, the Czech Republic, Slovakia, Slovenia, Poland - also switched to university ownership from a previous system of government ownership. The Republic of Korea, having broken into the group of high-income countries in the 1990s, has implemented Bayh-Dole-type policies since 2000.

Despite the overarching convergence to Bayh-Dole, university ownership systems have been implemented in different ways. For example, there are differences in the vesting of IP rights in the university: in some countries, the university is the first owner of the IP, while, in others, the IP is owned by the inventor, and the university has the right to claim it if it is not used within a certain period, or vice versa, the university has a time limit within which it has the right to claim ownership of IP, after which it reverts to the inventor. The scope of the policy also differs: in some countries, all inventions produced by academics fall under university ownership, while, in others, there are distinctions depending on whether the invention was developed in the course of their normal employment or outside it (see DLA Piper 2007, for a detailed analysis of the different systems).

The three middle-income countries considered in this book also followed the pattern of convergence to Bayh-Dole popular in Europe. 
However, as shown in Table 11.1, policy changes were implemented beyond the vesting of IP ownership rights in the university. Laws were passed to allow universities to license IP and to profit from it by allowing them to receive incomes from royalties. Universities were also obliged to compensate the inventor with a share of royalties. Brazil, China, and South Africa, which had previously limited the extent to which universities and public research institutes were permitted to engage with industry, began to relax these rules to allow universities much greater freedom of action. Laws were also passed so that public universities were given greater freedom to contract with industry, to establish spinoffs, and to allow academics to take leave of absence in order to engage in commercialization activities in their own or another firm.

More detail on the regulations that underpinned these changes in other middle-income countries is presented in WIPO (2011: Chapter 4) and in Zuniga (2011). This shows that the Bayh-Dole-inspired legislative reforms implemented in each country were usually a distinct package (e.g., in terms of the specific rules on the scope of university patenting, invention disclosure, incentives for researchers, and whether certain safeguards were instituted to counteract the potentially negative effects of patenting). Therefore, as argued in Chapter 1, what we term convergence to BayhDole was never a process of countries making simple binary choices with respect to institutional or individual patent ownership, but one with significant differences in the features of the whole package of policies.

Yet, in all cases, this new policy framework was justified by a "lack of commercialization of public research" argument: the idea that national universities in all countries produced good-quality research, which stayed locked up in ivory towers and which they failed to commercialize sufficiently. In other words, the problem was framed as one of lack of interaction between university and industry, which needed to be corrected by implementing changes in legal ownership rights and in incentives to encourage interaction between the actors in the system. As Arundel points out in Chapter 10, an absence of interactions between university and industry could also be caused by the failure of industry to "demand" knowledge from universities.

\subsection{Different Innovation Systems and Different Policy Mixes}

Chapter 2 detailed six different types of knowledge transfer channel from the public science base to industry. These ranged through research publications; conferences seminars and meetings with industry; 


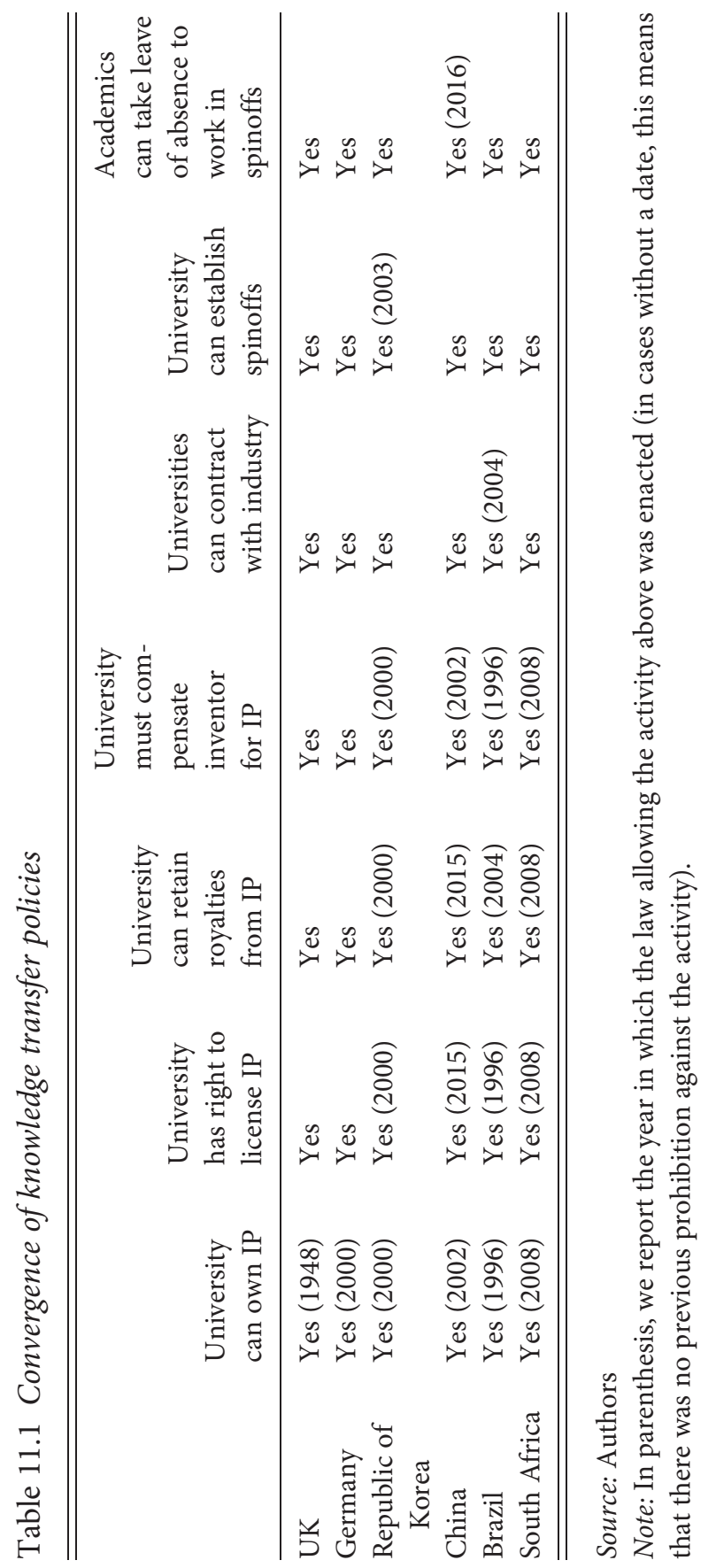


education and training of students/researchers recruited by the private sector; consultancies and contract innovation research (including university-industry joint research projects, joint research centers, and $\mathrm{PhD}$ projects); creation of IP for licensing; and creation of spinoff companies. A striking feature of knowledge transfer from the science base in middleincome countries lies in the fact that the last two forms of knowledge transfer are negligible and occur very rarely. This is clear from the country studies. One could, of course, argue that IP licensing and spinoff companies account for very small shares of overall university incomes even in high-income economies (see, for example, Chapter 4 and the evidence in WIPO 2011). This suggests in turn that the proportion of formal to informal knowledge transfer may not be the main indicator that sets high- and middle-income countries apart.

It is, of course, apparent that the institutional frameworks within the six country case studies (where Bayh-Dole-type measures were implemented) were very different. Further, none of these contexts (and set of packages) was similar to that of the U.S., the model that they appeared to be inspired by and aspired to. Some of the key differences between the six countries' innovation systems are summarized in Table 11.2, based on the country chapters and data in Chapter 1 . The first key difference is that firms' R\&D engagement is higher in high-income countries than in middle-income countries, as noted in Chapter 10. Interactions between public research and industry, and universities' research intensity, are also higher in high-income countries than in middle-income countries. The importance of public research institutes versus universities is variable. The Republic of Korea is a fascinating case as it presents some features that are intermediate between the two groups. Here, collaborative R\&D between public research institutes and private firms has been the most important and effective form of breaking into the higher-end segment of the industry (Lee et al. 2005; Lee 2013), whereas interactions between universities and industry have been low, although this has been changing since the 1990s.

The detailed case studies in this book, situated in a historical perspective, help us to appreciate the often overlooked point that what sets highand middle-income countries apart are that their innovation systems, and, more particularly, the system of production and transfer of knowledge between university and industry are quite different. In wellfunctioning high-income economies there are two-way flows of ideas and people between the university and industrial sectors. In middleincome economies, there is a healthy flow of people between universities 
Table 11.2 Differences between the national systems of innovation of six high-and middle-income countries

\begin{tabular}{|c|c|c|c|c|}
\hline & $\begin{array}{l}\text { Firms' R\&D } \\
\text { engagement }\end{array}$ & $\begin{array}{l}\text { Interactions } \\
\text { between pub- } \\
\text { lic research } \\
\text { and industry }\end{array}$ & $\begin{array}{l}\text { Importance of } \\
\text { research from } \\
\text { public } \\
\text { research insti- } \\
\text { tutes vs } \\
\text { universities }\end{array}$ & $\begin{array}{l}\text { Universities' } \\
\text { research } \\
\text { intensity }\end{array}$ \\
\hline UK & High & High & Low & High \\
\hline Germany & High & High & Medium & High \\
\hline $\begin{array}{c}\text { Republic of } \\
\text { Korea }\end{array}$ & High & High & High & Medium \\
\hline China & Low & Low & High & Low \\
\hline Brazil & Low & Low & Medium & Low \\
\hline South Africa & Low & Low & High & Low \\
\hline
\end{tabular}

Source: Authors

Note: The table builds on information provided in Chapter 1 and in the six country studies presented in this book and refers to the period considered in them. In most cases, firms' $\mathrm{R} \& \mathrm{D}$ engagement is measured in terms of $\mathrm{R} \& \mathrm{D}$ expenditure or $\mathrm{R} \& \mathrm{D}$ and patenting intensity of domestic firms. Interactions between public research and industry are measured in terms of firms' licensing of university patents and business funding of university research. Publications per academic are the most commonly used indicator of a university's research intensity.

and industry, but channels to establish a flow of ideas are very underdeveloped, and public research institutes are prominent as they bridge the gap between frontier science and its application to domestic industrial conditions. Thus, the success of Bayh-Dole-type policies in these economies needs to be judged not only by the vector of knowledge transfer outputs but also by the impetus that the legislation provided for establishing channels through which new ideas, emerging in universities, could find direct application in the industrial sector, without necessarily involving public research institutes in an intermediate role.

The stress in this chapter on links for people and ideas is thus complementary to the discussion of formal and informal channels of knowledge exchange outlined in Chapter 2. Formal methods of knowledge transfer and commercialization identified in that chapter are likely to require the institution of legal arrangements that favor the movement of ideas, while 
the movement of people is likely to favor more informal methods of knowledge exchange.

\subsubsection{High-Income Countries}

As noted in Chapter 1, high-income countries are characterized by high private expenditure in $\mathrm{R} \& \mathrm{D}$, with numerous large firms that employ R\&D staff and possess a high absorptive capacity for new technological knowledge and thus are able to interact with universities. In these countries, the university system is also highly developed, with many research-intensive universities. Although public research institutes are more (e.g., Germany, Republic of Korea) or less (e.g., United Kingdom) present in the system, in all cases, they are not the only source of research in the country: universities also play a prominent role. The Republic of Korea is slightly different from Germany, as public research institutes, although highly research-intensive, deal exclusively with large domestic firms and have struggled to establish links with smaller companies.

When the knowledge ecosystem is well developed we see two-way links between public research institutes, universities, and firms, as shown in Figure 11.1. The first link is through the movement of people, shown by the solid lines. Students may move to placements in firms and continue to collaborate with their former professors. Equally, managers of firms may draw on expertise in their alma mater to solve technical problems in the firms they are employed in. Similarly, public research institutes may invite secondments, allow the use of their R\&D labs, and develop joint R\&D projects. These people links, based on both institutionalized and interpersonal links, are distinct from arms' length transactions in technology and ideas through formal knowledge transfer.

The formal links, shown by the dashed lines in Figure 11.1, are likely to be based on the issue of patents, technology contracts, or equity investments. Patents are likely to be preferred in the case of mature, codifiable technologies, where licensing is a viable option because buyers can understand the technology quite readily (although evidence suggests that very often scientists who develop patented inventions continue to collaborate with licensing firms through consulting contracts, in order to support the implementation of the licensed technology; Thursby et al. 2001). Equity investment in spinoffs may make sense in the context of early-stage technologies, which cannot be easily codified and may need joint development with firms. 


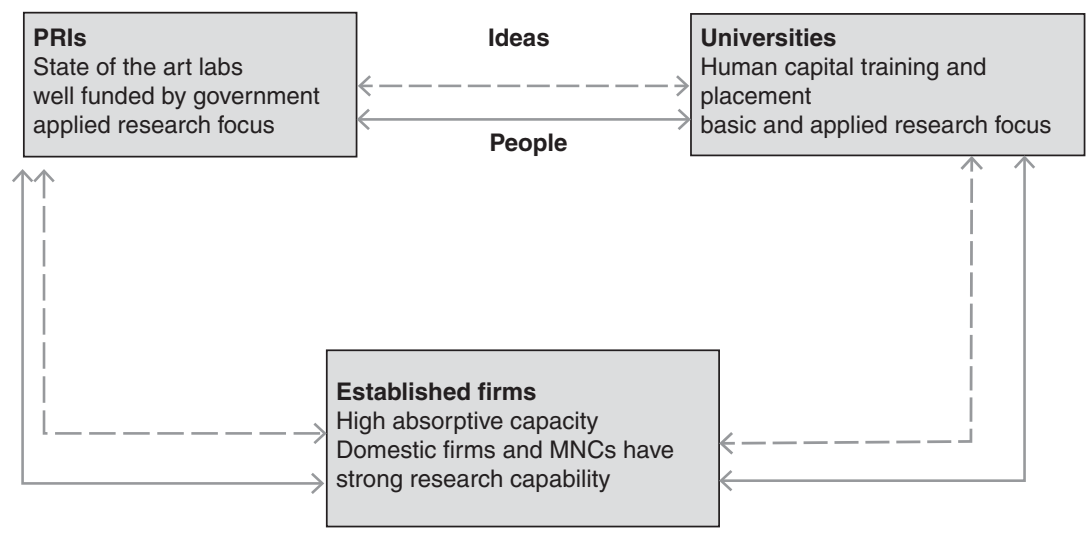

Figure 11.1 The knowledge ecosystem in high-income economies

In high-income economies, due to the presence of $\mathrm{R} \& \mathrm{D}$-intensive domestic firms and multinational corporations (MNCs) and of researchintensive universities and public research institutes (see also Chapter 10), both people and ideas circulate relatively frequently, through both institutionalized channels and well-established interpersonal relations. Indeed, for these countries, the assumption that a lack of interactions required new institutions was probably misleading. Certainly in Germany (see Chapter 5), there was not a lot of university patenting, and universities were not generating income from IP licensing, but a lot of knowledge transfer was happening without requiring university patents. Professors often collaborated directly with industry, either informally or through research contracts, and ceded their IP rights to their collaborating firms, which then patented the resulting inventions. Hence, although German universities owned few patents, professors often figured as inventors of industrially owned patents, a pattern that was present in most of continental Europe (Lissoni et al. 2008; Geuna and Rossi 2011).

The United Kingdom was an intermediate case, since it never had the professor's privilege and the IP rights to academic inventions belonged to the university, which initially ceded them to a central agency tasked with research commercialization, the British Technology Group. In spite of some successes (e.g., successful commercialization of the technology behind hovercrafts and magnetic resonance imaging), this approach did not lead to a large amount of commercialization: outside the medical sector, academics' interactions with industry were mostly either informal 
or focused on research contracting. Cambridge, which maintained a system of professor's privilege until 2005, saw intense involvement of professors in the development of spinoff companies, some of which spawned very large firms, particularly in ICT, which eventually generated a local high-technology cluster (Athreye 2004).

In the Republic of Korea, large firms were strong investors in $R \& D$ and had a very strong relationship with the government (chaebol system). Public research institutes played a greater role than universities in public $\mathrm{R} \& \mathrm{D}$ and knowledge transfer in the process of catch-up.

In these countries, characterized by preexisting strong interactions between universities, public research institutes, and firms, the introduction of Bayh-Dole-type legislation could disrupt as well as enhance interactions. In German-speaking and Scandinavian countries, as well as in Cambridge pre-2005, patents were owned by inventors, so the introduction of BayhDole-type legislation brought the patenting process further away from inventors; exactly the opposite of what had happened in the U.S., where patents were already owned by the Federal Government so the change brought the patenting process closer to inventors (Mowery and Sampat 2005). As a result, this process could disrupt existing relationships - which had developed in harmony with a system where inventors held IP rights rather than enhance them. Indeed, Chapter 5 argues that this is what happened in Germany, where, up to 2008, the change in policy reduced the number of patents by university academics by 17 percent and had no effect on the number of startups.

In the United Kingdom, which already had a system of university ownership for many universities, universities' obligation to commercialize their patents through the British Technology Group was removed in 1985. Since then, most universities have set up internal knowledge transfer offices (KTOs) dealing with commercialization activities. Given that in the United Kingdom individual academics could not dispose of their IP freely, most collaborations with industry already occurred with some involvement of the university institution, and there is little evidence of displacement effects. However, there is evidence that the increase in university patenting did not lead to the expected increase in licensing income, with licensing income concentrated in a few universities (see Chapter 4). ${ }^{1}$ There are signs of a decline in university patenting in recent years as universities are becoming more selective in which patents they pursue (Tang et al. 2010).

${ }^{1}$ Cross-country evidence in WIPO (2011) shows that in many countries only a handful of universities accounted for the bulk of the commercialization activities. 


\subsubsection{Middle-Income Countries}

In contrast to high-income countries, middle-income countries are characterized by a low number of R\&D-intensive firms, with the majority of domestic companies performing very little research and possessing low absorptive capacity, as discussed in Chapter 1. The few companies that perform R\&D tend to be MNCs, or companies that are partly government owned (e.g., the Brazil country study noted that 80 percent of patents generated in the country have nonresident applicants). These countries also tend to have a strong division of labor in knowledge production, with universities concentrating on basic research and the training of students, while public research institutes are tasked with adapting frontier research to the needs of industry and government. The data in Chapter 1 also show that in middle-income countries most research is performed in public research institutes funded by and responding to the government.

Figure 11.2 sketches the knowledge ecosystem in middle-income countries. The people links work well, and there are institutionalized links between public research institutes and firms. However, public research institutes tend to be strongly specialized by sector (very often, agriculture, engineering, and health), therefore interactions with firms are concentrated in particular industries and involve large firms. Furthermore, as the country studies of China, Brazil, and South Africa note, the links between public research institutes and industry are still limited outside of particular sectors or technology areas. One reason for this limitation may be the small size of many public research laboratories, which, with a few exceptions, do not produce world-leading research. This limited interaction may also be due to contractual laws that limit the employment of university researchers by other employers: for example, public research institutes in Brazil have only been allowed to sign knowledge transfer contracts with companies since 2004. The cultural chasm between scientists working in labs and industry staff may also be a factor. In many countries, pursuit of science and learning may be seen as a "pure" goal and one that should not be contaminated by commercial considerations. ${ }^{2}$

Our case studies suggest that in middle-income countries, the main difference when compared to Figure 11.1 for high-income countries is

${ }^{2}$ In India, for example, Saraswati (the goddess of learning) is said to leave the room when Lakshmi (the goddess of wealth) enters it. See https://devdutt.com/articles/battle-oflakshmi-and-sarawati.html. 


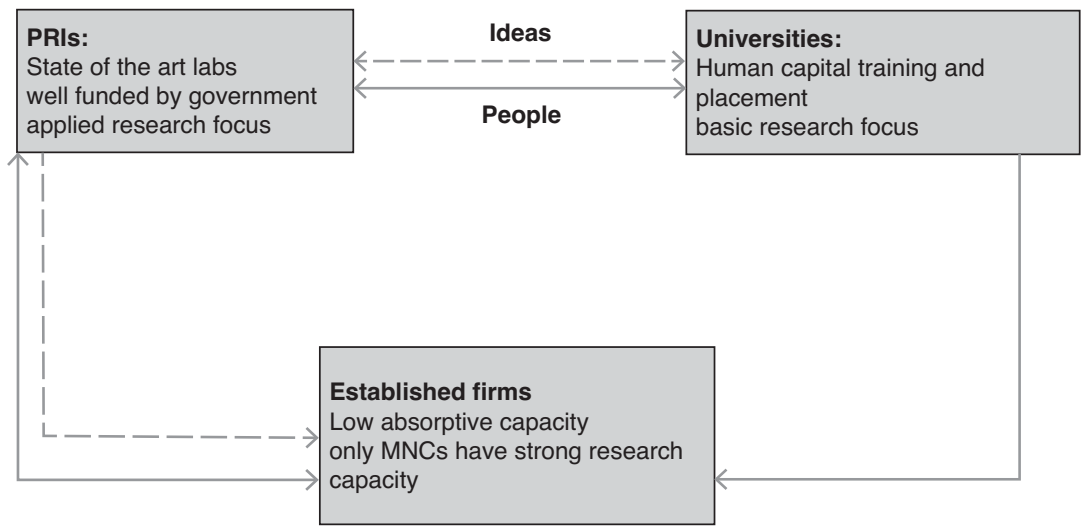

Figure 11.2 The public research ecosystem in middle-income economies

the presence of only weak linkages (and sometimes their complete absence) for transferring research ideas, knowledge, and technology from the university science base to industry. Universities in middleincome countries mainly engage in training and provide the human capital for both industry and public research institutes. These training links have resulted in informal people-mediated channels of knowledge transfer, but formal channels are largely limited - where present, they usually take the form of contract research and consulting. Interestingly, the Republic of Korea shows these features as well, despite being a highincome country.

The absence of linkages between university and industry poses two challenges for the implementation of knowledge transfer policies. As already noted in Chapter 10, universities have not yet developed a way to bridge the gap between the basic scientific research they produce and the prototype level of development of an innovative idea. Many firms require the latter to readily absorb and use to scale up production. The second challenge comes from the legal and contractual obligations surrounding university researchers, which are often not conducive to engagement with industry on research issues. Our case studies provide evidence of the full range of such challenges.

In all the middle-income countries studied in this book, the implementation of Bayh-Dole-inspired knowledge transfer policies encountered problems created by the missing (ideas) links between universities and industry and further rounds of policy changes were required to overcome the problems. Thus each of our country chapters also outlines a policy-induced process of adaptation of institutional frameworks that 
share some important similarities, but that also differ in several details. While the general policy discourse around the implementation of BayhDole-type legislation seemed to suggest that these changes in formal rules would, in themselves, be sufficient to achieve the hoped-for increases in commercialization activities, in practice, most countries have also implemented a range of supporting measures aimed at stimulating the creation of the infrastructures and competences that are required to connect university actors to industry. This includes rules to support exploiting the new IP rights framework, as well as measures to stimulate firms' demand for university IP (e.g., funds for joint research projects).

\subsubsection{Policy Mixes Adopted}

Analysis of the policy interventions enacted in the six country case studies can be subsumed under two major categories and related subcategories. The first category of complementary interventions aims to introduce supply-side incentives for universities to supply technology more readily and frequently to industry. These include institutional-level incentives for universities to patent and license IP and to interact with industry in different ways, for example, by establishing KTOs and other intermediaries encouraging interactions between universities and industry. These intermediaries manage research contracts, the creation of spinoffs, the establishment of joint research centers, and other related activities. In some cases, KTOs were established at local, regional or national levels, with or without the involvement of universities, and several universities "shared" KTO services.

As technology transactions are plagued by asymmetric information about the nature of technology and potential applications, individual researchers are in the best position to alleviate these concerns. In addition, the interpersonal networks of researchers can often be used to kickstart links with industry when none exists. Therefore, in all cases, supplyside measures also included incentives for individual academics to engage in knowledge transfer. Examples include monetary incentives that allow academics to receive income from royalties and consulting activities in addition to their salaries; career development incentives that include knowledge transfer performance as a criterion for academic promotion; incentives for academics to engage in entrepreneurial and other business activities, including permissions to take leave of absence in order to work for university spinoffs or for other companies, and to earn income from these activities. 
The second category of interventions consists of demand-side incentives for firms to engage with industry. These incentives range from general incentives for firms to invest in R\&D (such as R\&D tax credits, grants, innovation vouchers) and more specific incentives for firms to collaborate with universities and public research institutes (such as joint project grants, subsidies for the establishment of joint research centers, and mandatory investment in university research). All these incentives can be created purely through legal requirements, or they can involve the use of government funds, either in the form of government subsidies for certain activities or in the form of rewards for universities' good performance in certain activities.

Table 11.3 summarizes the extent to which the six countries implemented supply-side and demand-side incentives of the kinds just described. As can be seen, most countries implemented a combination of incentives. All of them focused on supply-side incentives, consistent with the argument that they saw the problem primarily as one of getting universities to reach out to industry.

Middle-income countries have mainly issued legal requirements for universities to engage with industry (although individual universities can enact their own internal policies providing academics with monetary incentives, for example, to develop spinoff companies or engage in consulting activities), while high-income countries have also dedicated government funds to supporting universities in these activities. All countries have invested public funds in the setup of KTOs (either within universities, or at local, regional, or national levels). In Brazil, while every public university and public research institute in the country is required to have a KTO, the Innovation Act allowed institutions to share a KTO, so that several of them serve more than one research institution.

On the demand side, all countries enacted specific monetary incentives for companies to interact with public research, mainly in the form of $\mathrm{R} \& \mathrm{D}$ tax breaks and opportunities to bid for joint R\&D projects. In Brazil, companies in some sectors such as energy are required to invest a share of their revenue in $R \& D$ in partnership with universities and public research institutes. This has been successful in stimulating university-industry interactions. However, this requirement applies to companies that are large, often multinationals headquartered outside Brazil, and benefits only a few research-intensive universities and public research institutes. The majority of public research institutes in Brazil continue to be too small and insufficiently research-intensive to benefit from these incentives. 


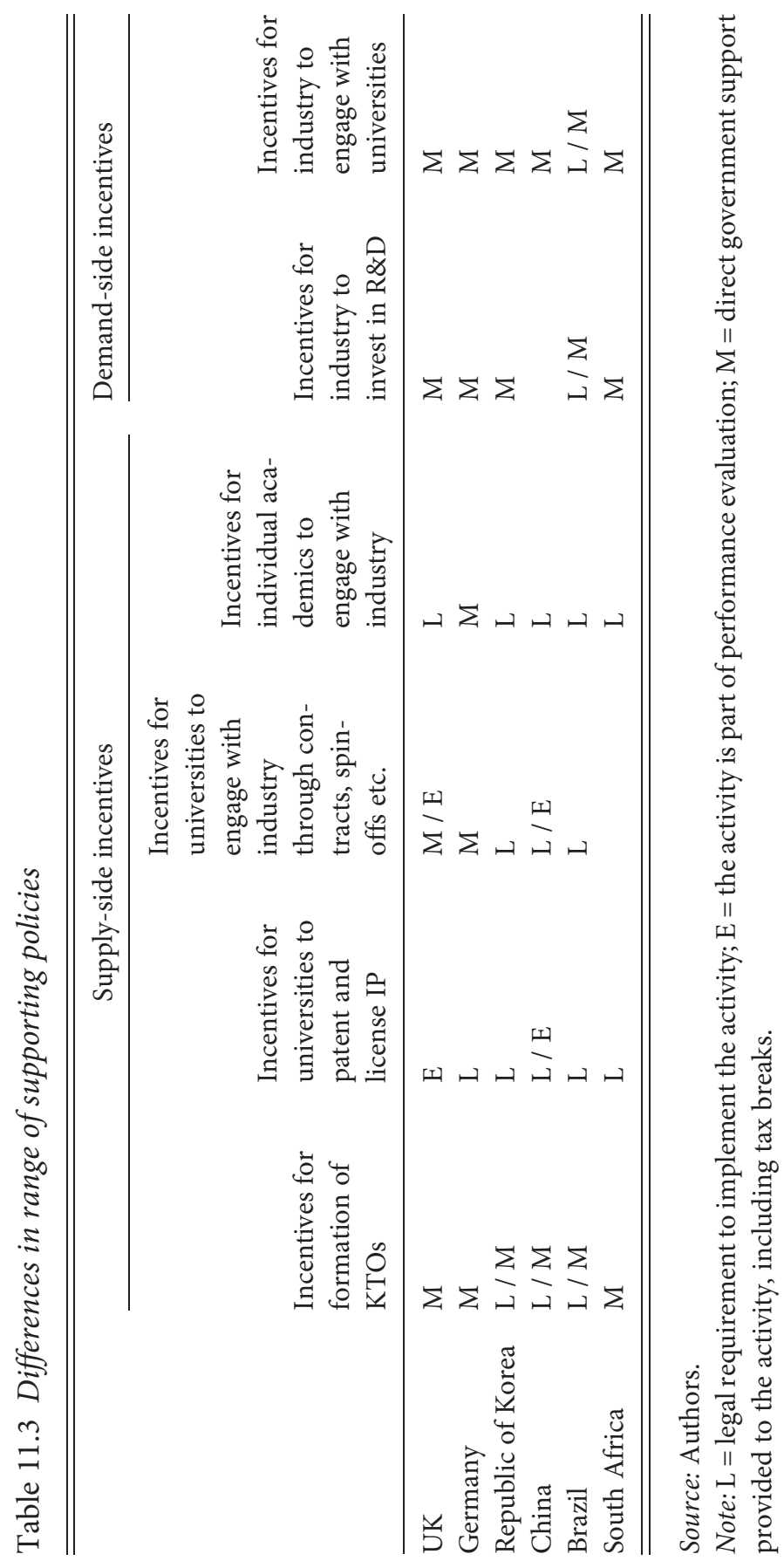


In addition, the case studies provide interesting insights into the timing and sequence of the policy changes. Almost all countries started by implementing legal changes but had to follow them up with a mixture of carrot (monetary incentives) and stick (performance evaluation) policies, to encourage take-up of these activities.

In Brazil, policy interventions implemented in 1996 allowed universities to own and license IP as well as compensating individual inventors. In 2004, the policy changed to allow universities to retain some income from licensing and to contract with industry. Universities and public research institutes were also required to have a KTO or use the services of a shared KTO, and were provided with some funding for this. ${ }^{3}$

Despite some increases in university patenting and licensing activities in Brazil, these supply-side incentives have had limited effectiveness in stimulating universities' interactions with industry, due to several problems, including lack of clarity, insufficient financial incentives for individual researchers, and limited resources and competences of KTOs, whose staff consist entirely of public servants. KTOs suffer from high staff turnover and a dearth of qualified or specialized staff, because their link to government institutions obliges them to rely on public tenders in hiring new staff and they do not offer competitive salaries. According to the MCTIC (2017), more than 50 percent of KTO staff had no previous experience in the private sector.

China started in 2002 by enacting laws that allowed university ownership of IP and compensation of inventors for their IP. More than a decade later (2015-16), it enacted a raft of measures allowing universities to profit from their IP (retain royalties, set up spinoff firms), and permitting academics to work for companies by taking leave of absence. One way of interpreting this lag is that the early experiments with researchers initiating links were ready to be institutionalized only a decade later. A remarkable feature of the Chinese case is the combination of monetary incentives and performance monitoring to achieve the objective of knowledge exchange. In this respect, the country's overall policy is similar to the case of the United Kingdom.

South Africa is the most recent country in our sample to have enacted knowledge transfer policies, and, in contrast to the other countries, they immediately allowed both individuals and universities to retain profits

3 There were a few open calls to grant fellowships for hiring people to work in KTOs in Brazilian universities in recent years. In 2006, there was a funding program from $\mathrm{CNPq}$ and FINEP to support the creation and implementation of KTOs. 
from their IP. In South Africa, the Council for Scientific and Industrial Research (CSIR) dominates the public research institute landscape and has highly specialized labs in the area of petrochemicals. CSIR also has extensive links with universities. The government has not provided direct funding to support universities' engagement with industry, but it has enacted some demand-side measures in the form of monetary incentives, which include the provision of funding for companies' R\&D, often in partnership with universities or public research institutes.

In the Republic of Korea, the government's promotion efforts were focused on encouraging interactions between domestic public research institutes and universities and firms, particularly SMEs, whose role in the economy the government intended to strengthen. They did so through incentives for commercialization but particularly through strengthening the KTO system through numerous measures. So far, efforts have not been as successful as was hoped (see Chapter 6). Large firms do interact with universities by establishing R\&D centers on the campuses of major universities, ${ }^{4}$ although they have tended to invite and hire star professors (mostly Korean) from universities located abroad. SMEs lack absorptive capacity and consequently need technologies to be provided at a higher level of technological readiness. This has been stymied by a research funding model that provides funds on a project basis, with funding often terminated before a discovery is developed sufficiently.

\subsection{An Ideal Policy Mix?}

If one form of legislation cannot fit all circumstances, how should policymakers decide which polices to adopt? Clearly the objectives of policies to support knowledge transfer from universities will be different in high- and middle-income countries and may even differ among universities within the country.

In high-income countries, the main challenge facing knowledge transfer policies is the need to avoid displacement. As patent-mediated commercialization processes can produce very high financial rewards, it may be important to ensure that financial constraints do not push universities to prefer any one kind of commercialization. Thus, first, funding to universities should be increased so that different channels of commercialization are not substituted for one another. Second, universities should try to

${ }^{4}$ For instance, Samsung Electronics and Hyundai Motors have R\&D centers on the campus of Seoul National University. 
promote a broad range of interactions outside formal channels, such as through the involvement of alumni active in research - often in other countries. In recent years, the United Kingdom has sought to redress the imbalance in perceptions of value by inclusion of research impact as an important evaluation criterion on a par with patents and publications in research-active universities. Last, the policy focus on rewarding IP ownership should subtly shift to encourage and reward IP use by universities or firms rather than ownership per se. This could take the form of recognizing impact (as in United Kingdom universities) or take the form of a subsidy that could be used by the department or inventor as income for further research.

In middle-income countries, interactions between university and industry face greater challenges and may need more policy intervention. In these countries, the knowledge ecosystem is relatively immature and research interactions between universities and industries are generally lacking (except for a few interactions involving large, multinational firms and a few highly research-intensive universities and public research institutes) due to weaknesses on both sides.

A first problem confronting middle-income country governments is the overall limited research intensity of their universities due to a traditional focus on teaching. Several additional factors reinforce this low research intensity. Universities have traditional incentive structures that reward teaching over commercialization and industry engagement. Additionally, universities find it difficult to retain their brightest and their best. Policies to correct these problems include allowing the university and inventor to profit from knowledge transfer and research, in part, by ensuring that extra profits are not taxed away as higher income - that is, ensuring that there is a financial incentive to use scientific knowledge and plow back the investments from it.

A second problem confronting policymakers in middle-income countries is the small volume of (or nonexistent) industry interactions. When such interactions are nonexistent because the contractual obligations of university researchers do not allow self-employment or employment by others (e.g., through research contracts), then legal changes may be needed to permit such interactions to take place. If there are no legal barriers, then establishing contacts may require the active involvement of the researcher and direction by knowledge transfer specialists with knowledge of industry needs and an understanding of university researcher contexts. In high-income economies such roles are usually played by KTOs, which is warranted when there is a large volume of 
technology transactions. In middle-income economies, the small volume of transactions may not warrant a specialist centralized intermediary to aid and advise the university. In the short term, universities may also gain by interacting more closely with public research institutes, which were historically set up to translate frontier technology into applicable technology for local industries. There is some evidence that South African and Indian CSIR laboratories are doing this for particular sectors, and utilizing existing public research institutes may offer a more resourceefficient method of knowledge exchange than establishing new KTOs.

The third problem facing middle-income countries is the lack of a culture of interaction with industry and lack of awareness of commercialization possibilities. KTO staff are usually career civil servants, governed by civil service rules and promotion policies. Staffing KTOs with scientists familiar with industrial R\&D is extremely important to changing the culture of interaction between university and industry. Policies that target the recruitment into management positions of scientists who had some training abroad could also help to change the research culture in universities. This has been done extremely successfully in China and Singapore.

Chapter 10 has offered a number of suggestions for improving firms' uptake of technology produced in universities and we will not repeat them here except to note that offering joint funds for exploitation with university partners may both alleviate the low research intensity of existing firms and encourage them to search for the best university partners and so make it mutually beneficial for universities and firms to establish links around research and the commercialization of research.

We summarize our arguments in Figure 11.3, which outlines five questions that governments and universities must ask themselves before deciding on the appropriate policy mix.

\subsection{Summary}

Our concern in this chapter has been to look more closely at the policyinduced convergence of the knowledge ecosystem that the Bayh-Doletype legislation in various countries attempted, drawing on the extensive material of the country case studies. Our analysis suggests that in highincome countries, such as the United Kingdom and Germany, where the knowledge ecosystems were already well developed and mature, the adoption of Bayh-Dole-type legislation while simultaneously cutting back on government funding of research in universities and public 


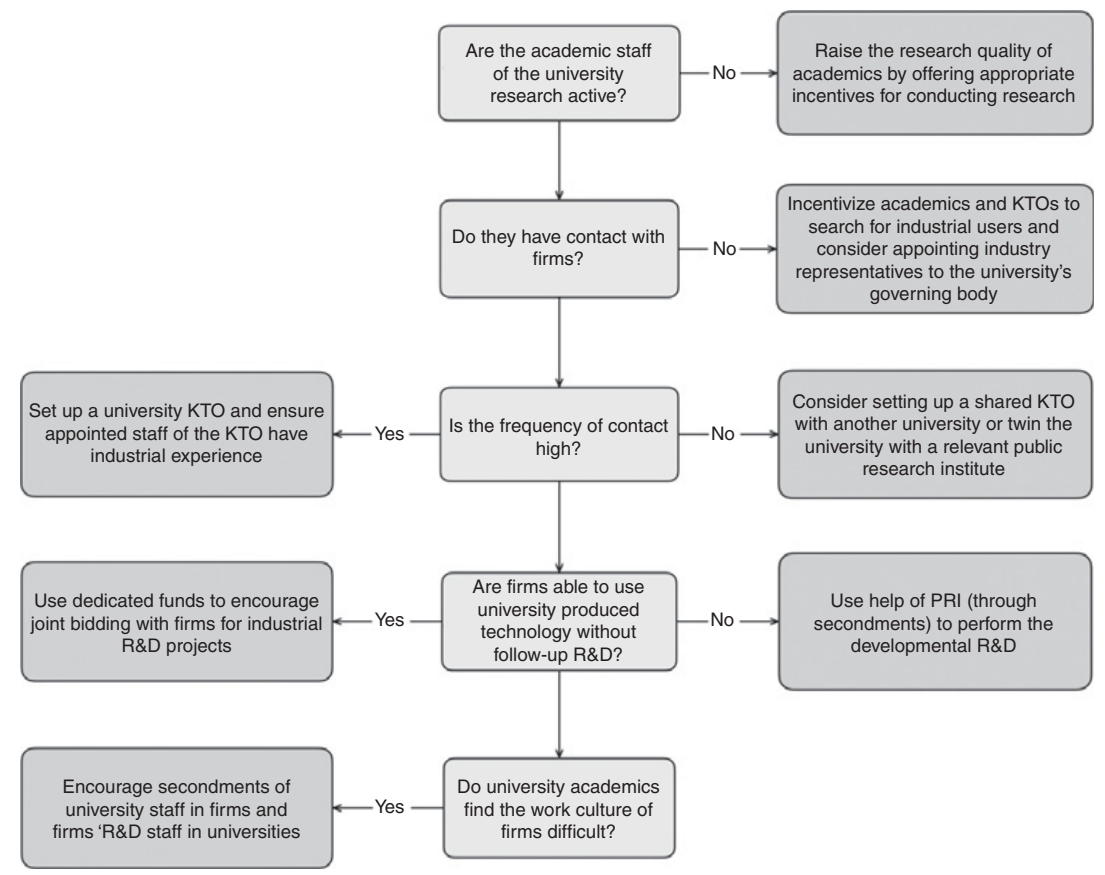

Figure 11.3 Five questions to guide policy toward knowledge exchange from universities

research institutes created the risk of "displacement effects." By displacement effects, we mean research expected to produce patents being incentivized and preferred (due to its higher expected value) over other types of commercialization, such as more informal and risky codeveloped research (in spinoff firms or with domestic firms). Despite this, the data show that non-IP methods such as contract research are a much bigger income earner, even in the United Kingdom, than research-producing patents for licensing, while overall income from knowledge transfer has remained steady as a proportion of university incomes. This could be because patent use was harder to achieve than patent ownership and/or in many research fields, contract research, or the development of applications in spinoff firms were simply better avenues of commercialization.

In middle-income economies, where knowledge ecosystems were less mature, with missing links in the knowledge ecosystem, the Bayh-Dole legislation kick-started a process of institutional reform. Middle-income 
countries often needed to adopt a complementary set of policies (in stages) in addition to permitting university ownership of IP. In most countries in our study, the requirement that universities undertake research that benefits industry was supported by a generous allocation of financial resources to enable such a transformation. The role that policy played in plugging institutional gaps is interesting (although it differs from country to country) and may, in time, deliver the desired outcome of an increase in the value of university research for the innovation activities of national firms.

The chapter concludes by noting that there cannot be a one-size-fits-all policy and enumerates a number of university-level factors that should be taken account of in middle- and low-income economies in order to deliver an effective knowledge transfer policy.

\section{References}

Athreye, S. (2004). "Agglomeration and growth: A study of the Cambridge high tech cluster." In T. Breshanan and A. Gambardella (eds.), Building HighTech Clusters: Silicon Valley and Beyond. Cambridge: Cambridge University Press.

Berman, E.P. (2008). "Why did universities start patenting? Institution-building and the road to the Bayh-Dole Act." Social Studies of Science, 38: 835-71.

Block, F. (2008). "Swimming against the current: The rise of a hidden developmental state in the United States." Politics and Society, 36(2): 169-206.

Bozeman, B. (1994). "Evaluating government technology transfer: Early impacts of the "cooperative technology paradigm." Policy Studies Journal, 22(2): 322-7.

Colaianni, A. and R. Cook Degan (2009). "Columbia University's Axel patents: Technology transfer and implications for the Bayh-Dole Act." Millbank Quarterly, 87(3): 683-715.

DLA PIPER, Mason Hayes+Currant (2007). Monitoring and Analysis of Technology 842 Transfer and IPRs and Their Use - Professor's Privilege. Report for the European 843 Commission (DG research).

Feldman, M., A. Colaianni, and K. Liu (2005). Commercializing Cohen-Boyer 1980-1997. DRUID Working Paper 05-21.

Geuna, A. and F. Rossi (2011). "Changes to university IPR regulations in Europe and the impact on academic patenting." Research Policy, 40(8): 1068-76.

Graff, G.D. (2007). "Echoes of Bayh-Dole: A survey of intellectual property and technology transfer policies in emerging and developing economies." In R. Mahoney, A. Krattiger, L. Nelsen et al. (eds.), Intellectual Property Management in Health and Agricultural Innovation: A Handbook of Best Practices. Davis: CAL MIHR-USA. 
Kenney, M. and D. Patton (2009). "Reconsidering the Bayh-Dole Act and the current university invention ownership model." Research Policy, 38 (9): $1407-22$.

Lee (2013). "Capability failure and industrial policy to move beyond the middleincome trap: From trade-based to technology-based specialization." In J.E. Stiglitz and J.Y. Lin (eds.), The Industrial Policy Revolution I. International Economic Association Series. London: Palgrave Macmillan.

Lee, K., L. Chaisung, and W. Song (2005). "Emerging digital technology as a window of opportunity and technological leapfrogging: Catch-up in digital TV by the Korean firms." Industrial Journal of Technology Management, 29(1/2): 40-63.

Lissoni, F., P. Llerena, M. McKelvey, and B. Sanditov (2008). "Academic patenting in Europe: New evidence from the KEINS database." Research Evaluation, 17(2): 87-102.

Ministério da Ciência, Tecnologia, Inovações e Comunicações (MCTIC) (2017). Política de Propriedade Intelectual das Instituições Científicas e Tecnológicas do Brasil - Relatório FORMICT 2017. Brasilia: MCTIC. Available at www .mctic.gov.br/mctic/export/sites/institucional/tecnologia/propriedade_intelec tual/arquivos/Relatorio-Formict-Ano-Base-2016.pdf. Accessed January 2018.

Mowery, D.C. and B. Sampat (2005). “The Bayh-Dole Act of 1980 and universityindustry technology transfer: A model for other OECD governments?” Journal of Technology Transfer, 30(1-2): 115-27.

Powers, J. (2006). "Patents and royalties." In D.M. Priest and E.P. St John (eds.), Privatization and Public Universities in Priest. Bloomington, IN: Indiana University Press.

Sampat, B. (2009). "Patenting and US academic research in the 20th Century: The world before and after Bayh-Dole.” Research Policy, 35(6): 772-89.

Saxenian, A. (1994). Regional Advantage: Culture and Competition in Silicon Valley and Route 128. Cambridge, MA: Harvard University Press.

Saxenian, A. (2007). The New Argonauts: Regional Advantage in a Global Economy. Cambridge, MA: Harvard University Press.

Schacht, W.H. (2005). The Bayh-Dole Act: Selected Issues in Patent Policy and the Commercialization of Technology. Congressional Research Service Report for US Congress.

Storper, M. and R. Walker (1983). "The theory of labour and the theory of location." International Journal of Urban and Regional Research, 7(1): 1-43.

Tang, P., D. Weckowska, A. Campos, and M. Hobday (2010). Managing Intellectual Property in Universities: Patents and the Protection Failure Problem. Final Report prepared for the Gatsby Charitable Foundation. (SPRU Working Paper Series 188). Brighton: Science and Technology Policy Research, University of Sussex. 
Thursby J., R. Jensen, and M. Thursby (2001). "Objectives, characteristics and outcomes of university licensing: A survey of major U.S. universities." Journal of Technology Transfer, 26: 59-72.

WIPO (2011). "Harnessing public research for innovation - the role of intellectual property." In World Intellectual Property Report 2011: The Changing Face of Innovation. Geneva: World Intellectual Property Organization (WIPO). www.wipo.int/edocs/pubdocs/en/wipo_pub_944_2011-chapter4.pdf.

Zucker, L.G., M.R. Darby, and M.B. Brewer (1998). "Intellectual human capital and the birth of US biotechnology enterprises." American Economic Review, 88(1): 290-306.

Zuñiga, P. (2011). The State of Patenting at Research Institutions in Developing Countries: Policy Approaches and Practices, WIPO Economics Research Working Papers No. 4, Geneva: WIPO, http://www.wipo.int/edocs/pubdocs/ en/wipo_pub_econstat_wp_4.pdf. 